\title{
Involvement of the Chromosomal Translocation $t(11 ; 18)$ in Some Mucosa-Associated Lymphoid Tissue Lymphomas and Diffuse Large B-Cell Lymphomas of the Ocular AdnexaEvidence from Multiplex Reverse Transcriptase-Polymerase Chain Reaction and Fluorescence In Situ Hybridization on Using Formalin- Fixed, Paraffin-Embedded Specimens
}

\author{
Shinichi Takada, M.D., Tadashi Yoshino, M.D., Ph.D., Masafumi Taniwaki, M.D., Ph.D., \\ Naoya Nakamura, M.D., Ph.D., Hirokazu Nakamine, M.D., Ph.D., Koichi Oshima, M.D., Ph.D., \\ Yoshito Sadahira, M.D., Ph.D., Hiroshi Inagaki, M.D., Ph.D., Koichi Oshima, M.D., Ph.D., \\ Akagi Tadaatsu, M.D., Ph.D.
}

Department of Pathology, Okayama University Graduate School of Medicine and Dentistry, Okayama (ST, TY, AT); Third Department of Internal Medicine, Kyoto Prefectural University of Medicine, Kyoto (MT); Department of Pathology, Fukushima University of Medicine, Fukushima (NN); Department of Clinical Laboratory Medicine, Wakayama University School of Medicine, Wakayama (HN); First Department of Pathology, Fukuoka University School of Medicine, Fukuoka (KO); Department of Pathology, Kawasaki University Medical School, Kurashiki (YS); Department of Pathology, Nagoya City University Medical School, Nagoya (HI); and Department of Ophthalmology, National Okayama Medical Center, Okayama (KO), Japan

The chromosomal translocation $t(11 ; 18)$ is a unique chromosomal aberration associated with mucosaassociated lymphoid tissue lymphoma. API2 and MALT1 genes have been identified around this translocation. We attempted to find chromosomal abnormalities focusing mainly on the $t(11 ; 18)$ translocation in formalin-fixed, paraffin-embedded tissues of ocular adnexal lymphoproliferative disorders using multiplex reverse transcriptasepolymerase chain reaction and/or two-color interphase fluorescence in situ hybridization. By these methods, the $t(11 ; 18)$ translocation was detected in 1 of 8 patients with reactive lymphoid hyperplasia (13\%), 3 of 23 with mucosa-associated lymphoid tissue lymphoma (13\%), and 2 of 14 with diffuse large B-cell lymphoma with/without mucosa-associated lymphoid tissue lymphoma (14\%). Moreover, we performed fluorescence in situ

Copyright (C) 2003 by The United States and Canadian Academy of Pathology, Inc.

VOL. 16, NO. 5, P. 445, 2003 Printed in the U.S.A.

Date of acceptance: February 18, 2003.

Address reprint requests to: Tadaatsu Akagi, M.D., Ph.D., Department of Pathology, Okayama University Graduate School of Medicine and Dentistry, 2-5-1 Shikata-cyo, Okayama 700-8558, Japan; fax: 81-22-86-2357156; e-mail: akagi@cc.okayama-u.ac.jp.

DOI: 10.1097/01.MP.0000067421.92575.6E hybridization analysis to detect any numerical aberration of chromosomes $3,7,12$, and 18 on some specimens nonselectively. No numerical chromosomal abnormalities were detected in 3 cases of reactive lymphoid hyperplasia, whereas three of four cases of mucosa-associated lymphoid tissue lymphoma and all four cases of diffuse large B-cell lymphoma with/without mucosa-associated lymphoid tissue lymphoma components exhibited one or more abnormalities. These findings indicate a possibility that at least in the ocular adnexa, some diffuse large B-cell lymphomas are derived from mucosa-associated lymphoid tissue lymphomas.

KEY WORDS: Chromosomal translocation, Diffuse large B-cell lymphoma, Fluorescence in situ hybridization, Mucosa-associated lymphoid tissue lymphoma, Ocular adnexa, RT-PCR.

Mod Pathol 2003;16(5):445-452

Mucosa-associated lymphoid tissue (MALT) lymphoma was first described in 1983 by Isaacson and Wright (1). Since then, its clinicopathological features have been well characterized, and the REAL (2) and WHO classifications (3) have categorized it as a distinct lymphoma type. MALT lymphomas arise in numerous organs that lack native lymphoid 
tissues but which acquire MALT associated with chronic inflammatory processes triggered by autoimmune phenomena and/or chronic infection. Recent studies have revealed the recurrent chromosomal aberration in MALT lymphomas: trisomies 3, 7, 12, and 18 (4-8); t(1;14)(p22;q32) (9, 10); and $\mathrm{t}(11 ; 18)(\mathrm{q} 21 ; \mathrm{q} 21)(10-16)$. The chromosomal translocation $\mathrm{t}(11 ; 18)(\mathrm{q} 21 ; \mathrm{q} 21)$ represents the most frequent structural chromosomal abnormality in MALT lymphoma, resulting in the production of API2-MALT1 fusion transcripts (14-16). Interestingly, this translocation has not been detected in diffuse large B-cell lymphomas of the stomach, although some diffuse large B-cell lymphomas are known to be associated with MALT lymphoma (11, 16).

The ocular adnexa is a site frequently affected by MALT lymphoma, but chromosomal abnormalities of ocular adnexal lymphoproliferative disorders have not been well clarified yet. We previously reported clinicopathological data on these disorders (17). In this study, we attempted to clarify chromosomal abnormalities in ocular adnexal lymphoproliferative disorders such as reactive lymphoid hyperplasia, MALT lymphoma, and diffuse large B-cell lymphoma, mainly focusing on the $t(11 ; 18)(q 21$; q21) translocation.

\section{MATERIALS AND METHODS}

\section{Cases}

Formalin-fixed, paraffin-embedded tissue specimens of ocular adnexal lesions were retrieved from files dated between 1989 and 2000 of the Department of Pathology, Okayama University Medical School and from consultation files. Hematoxylin and eosin-stained sections were re-evaluated, and so we changed diagnosis from pseudolymphoma to reactive lymphoid hyperplasia in 7 cases, from diffuse lymphoma, medium-sized cell type to MALT lymphoma in 11 cases, and from diffuse lymphoma, mixed cell type to MALT lymphoma with diffuse large B-cell lymphoma in 1 case. Forty-five consecutive cases of lymphoproliferative disorders were chosen for this study: 8 cases of reactive lymphoid hyperplasia (Fig. 1A), 23 of MALT lymphoma, 2 of diffuse large B-cell lymphoma with MALT lymphoma (Fig. 1, B-D), and 12 of diffuse large B-cell lymphoma without MALT lymphoma. All patients were Japanese adults. The clinical features of each diagnostic category are summarized in Table 1.

The patient (Case 1) with reactive lymphoid hyperplasia died of non-Hodgkin's lymphoma, diffuse large B-cell lymphoma that developed in lymph nodes and the parotid glands but did not involve the orbit. MALT lymphoma was diagnosed not only histologically but also by confirming the clonality
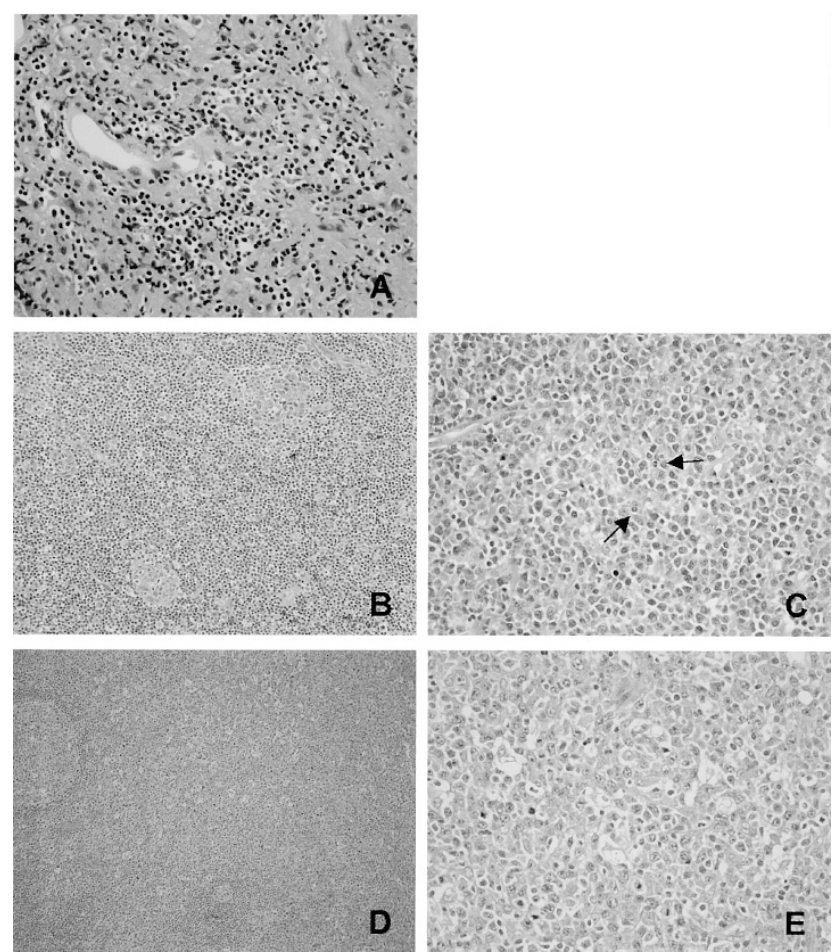

FIGURE 1. Reactive lymphoid hyperplasia (A) and primary MALT lymphoma with diffuse large B-cell lymphoma (B-E). A (Case 2); note infiltrating lymphoid cells show small cells and no atypia. B, C (Case 32), lesions of MALT lymphoma; note lymphoma cells show differentiate plasmacytes with Datcher bodies. D, E (Case 32), lesions of diffuse large B-cell lymphoma; note lymphoma cells show large cells and severe atypia.

using immunohistochemical Ig light-chain restriction. Histological criteria described by Isaacson and Norton (18) were applied for diagnosis of MALT lymphomas. Immunoglobulin gene rearrangements were never detected in the cases of reactive lymphoid hyperplasia by PCR and/or Southern blotting analyses.

\section{Fluorescence In Situ Hybridization}

The interphase FISH assay was established by selecting YAC DNA clones flanking the breakpoint regions of $11 \mathrm{q} 21$ and $18 \mathrm{q} 21$ in the $t(11 ; 18)(q 21 ; q 21)$ translocation $(19,20)$. YAC clone $966 \mathrm{e} 4$ was chosen from the centromeric side of the 11q21 breakpoint. Similarly, YAC clones $943 \mathrm{~b} 8$ and $845 \mathrm{c} 5$ were chosen from the telomeric and the centromeric sides of the 18q21 breakpoint, respectively. After amplification of human sequences by Alu-PCR (21), probes for FISH were generated by a nick translation kit with spectrum orange- and spectrum green-labeled d-UTP (Vysis Inc., Downers Grove, IL). FISH was performed on cells isolated from paraffin sections according to the standard protocols $(22,23)$. In normal interphase cells, hybridization resulted in close spatial relation of the differentially labeled YAC clones, y845c5 and y943b8, leading to two red/ green signal pairs per nucleus, and in wide spatial 
TABLE 1. Clinicopathological Features of Each Histological Category

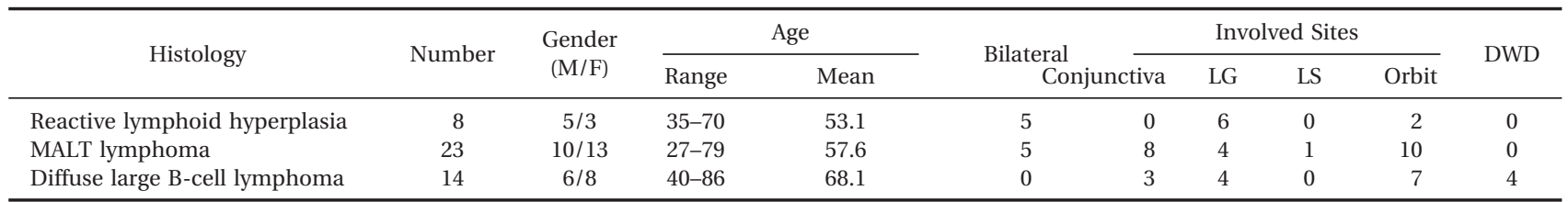

MALT = mucosa-associated lymphoid tissue; LG = lacrimal gland; LS = lacrimal sac; DWD = died with disease.

* Including diffuse large B-cell lymphoma and diffuse large B-cell lymphoma with MALT lymphoma.

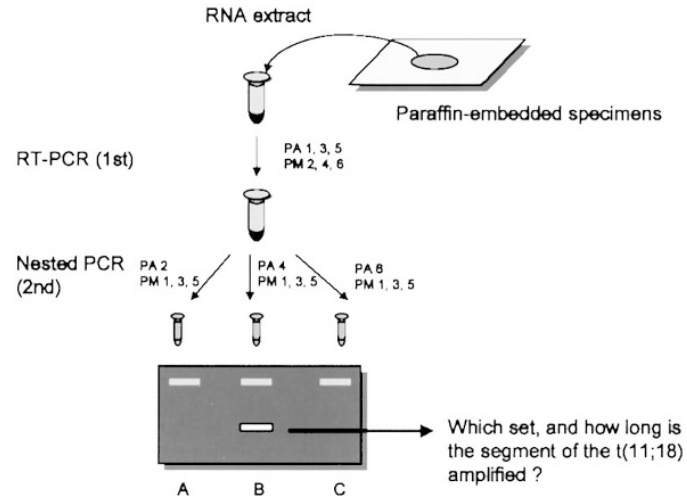

FIGURE 2. Flow diagram of multiplex reverse transcriptasepolymerase chain reaction

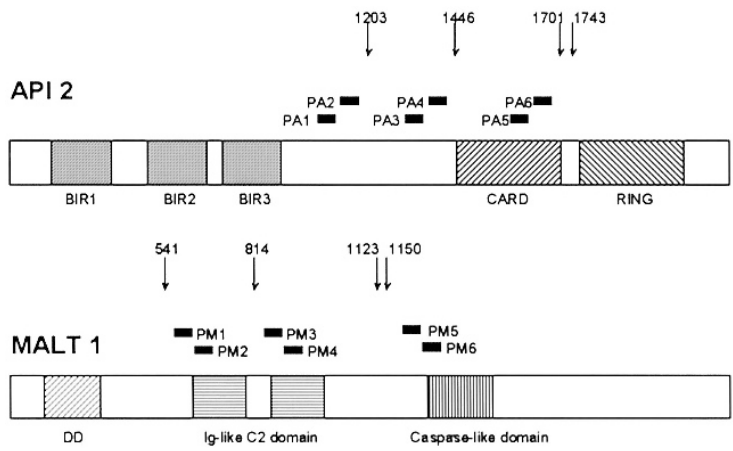

FIGURE 3. Locations of API2 and MALT1 breakpoints and primers for multiplex RT-PCR assay. The arrows indicate API2 and MALT1 breakpoints previously reported. Numbering is in accordance with the accession number L49432 for API2 and with the accession number AF130356 for MALT1.

relation of the differentially labeled YAC clones, y943b8 and y966e4, leading to two red signals and two green signals per nucleus. In cells carrying the $\mathrm{t}(11 ; 18)(\mathrm{q} 21 ; \mathrm{q} 21)$ translocation, a derivative signal constellation with one red/green signal pair and separately spaced red and green signals per nucleus were observed, using each YAC clone pair. Centromere-specific probes (Vysis) of chromosomes 3, 7, 12, and 18 were used for analysis of numerical chromosomal aberration. To determine the cutoff level in normal interphase nuclei, specimens from the four lymph nodes served as a negative control. For evaluation of FISH analysis, 100200 intact nuclei per case were observed on an Olympus $\mathrm{BH} 2$ fluorescence microscope.

\section{Multiplex Reverse Transcriptase (RT)-PCR}

API2-MALT1 fusion transcripts were detected by multiplex RT-PCR comprised of the first-round multiplex one-tube RT-PCR and three subsequent parallel multiplex nested PCRs, as described elsewhere (24). Briefly, total RNA was extracted from deparaffinized paraffin sections, and $5 \mathrm{~mL}$ of RNA solution was subjected to the first-round one-tube RT-PCR. Three different primer pairs (PA1-PM2, PA3-PM4, and PA5-PM6) were added to the reaction mixture containing Moloney murine leukemia virus reverse transcriptase (Life Technology, Tokyo, Japan), the deoxynucleotides, and TaqGOLD DNA polymerase (Applied Biosystems, Foster City, CA). After reverse transcription and PCR, the first-round RT-PCR product diluted with water to 1:16 was subjected to the three parallel second-round multiplex nested PCRs. Primers PA2, PM1, PM3, and PM5 were used to detect fusion genes possessing an API2 breakpoint at bp 1203 (second PCR-A); PA4, PM1, PM3, and PM5 were used for bp 1446 (second PCR-B); and PA6, PM1, PM3, and PM5 were used for bp 1701 or 1743 (second PCR-C; Figs. 2, 3, Table 2).

For the internal positive control, we amplified the ubiquitously expressed beta-actin mRNA.

\section{RESULTS}

The chromosomal translocation $\mathrm{t}(11 ; 18)(\mathrm{q} 21$; q21) was analyzed by FISH in eight cases of primary

TABLE 2. Oligonucleotide Sequences of Primers

\begin{tabular}{cl}
\hline Primer & \multicolumn{1}{c}{ Sequence } \\
\hline PA1 & ttcatccgtcaagttcaagc \\
PA2 & agccagttaccctcatctac \\
PA3 & ttactcaatgcagaagatga \\
PA4 & gaaataagggaagaggagag \\
PA5 & caagagaactgattgatacg \\
PA6 & attgcagccactgtattcag \\
PM1 & cagccaagactgcctttgac \\
PM2 & ttgaacaaaaggatgtccag \\
PM3 & ggcatcagctttgggaagt \\
PM4 & actgtaaaaccaatgtgctg \\
PM5 & aaaggctggtcagttgttg \\
PM6 & ttcctatcaaagggcaacc \\
AC1 & gagcaagagaggcatcct \\
AC2 & cagtggtacggccagagg \\
AC3 & tggagaaaatctggcaccac \\
AC4 & gaggcgtacagggatagcac \\
\hline
\end{tabular}

PA1-6, AC1, and AC3, sense primers; PM1-6, AC2, and AC4, antisense primers. 


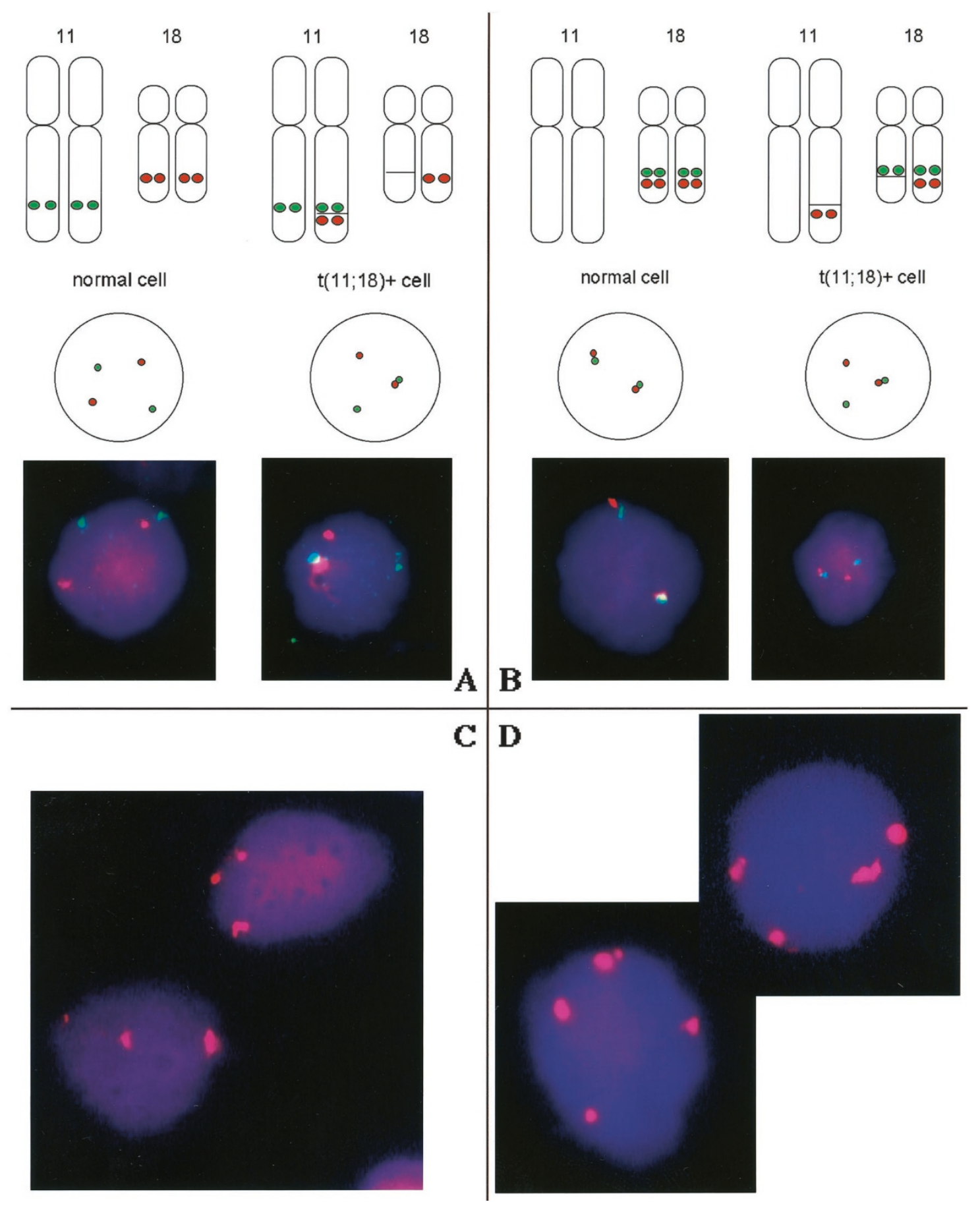

FIGURE 4. Two-color FISH for the $t(11 ; 18)(\mathbf{A}, \mathbf{B})$ and FISH for numerical aberration of chromosomes (C, D). A, FISH for the $t(11 ; 18)$ using YAC clones y943b8 and y 966e4. The $\mathrm{t}(11 ; 18)+$ cells show one red/green signal pair, one red signal, and one green signal per nucleus (right). Normal cells show two red signals and two green signals per nucleus $(\boldsymbol{l e f t})$. Case 17. B, FISH for the $\mathrm{t}(11 ; 18)$ using YAC clones y845c5 and y943b8. The $\mathrm{t}(11 ; 18)+$ cells show one signal pair, one red signal, and one green signal per nucleus (right). Normal cells show two signal pairs per nucleus (left). Case 39. C, FISH with chromosome 3 centromere-specific probe. Trisomy 3 is observed. Case 38. D, FISH with chromosome 18 centromere-specific probe. Tetrasomy 18 is observed. Case 36 .

ocular adnexal malignant lymphomas (4 MALT lymphomas, 1 diffuse large B-cell lymphoma with MALT lymphoma and 3 diffuse large B-cell lymphomas without MALT lymphoma) and three cases of reactive lymphoid hyperplasia. FISH showed the $t(11 ; 18)(q 21 ; q 21)$ translocation in one of four cases of MALT lymphoma and in one of three cases of diffuse large B-cell lymphoma without MALT lymphoma (Fig. 4, A-B). Numerical aberration of chromosomes 3, 7, or 18 was detected in five of eight cases of malignant lymphoma examined by FISH (Fig. 4, C-D). Especially, all diffuse large B-cell lymphoma with or without MALT lymphoma exhibited polysomies. In contrast, only one of four cases of 
(bp) M P N A B C D E

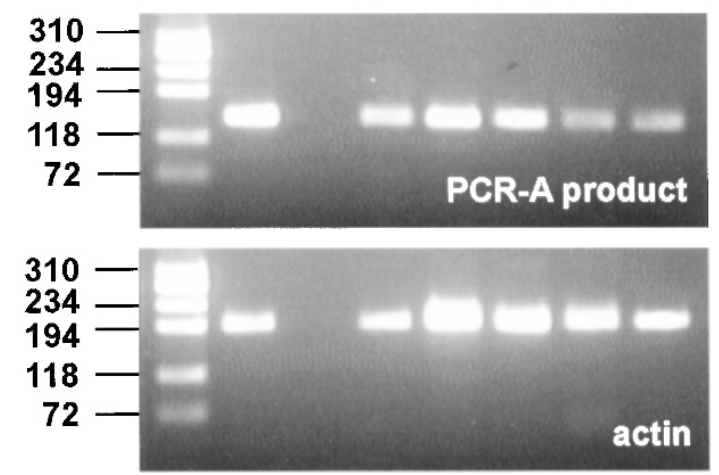

FIGURE 5. Reverse transcriptase-polymerase chain reaction analysis of lymphoproliferative disorders in the ocular adnexa. Lane M, Phi $\times$ 174 DNA HaeIII digest (72, 118, 194, 234, 271, 281, 310 bp); Lane P, positive control; Lane $\boldsymbol{N}$, negative control; Lane A, Case 2 (reactive lymphoid hyperplasia); Lane B, Case 19 (MALT lymphoma); Lane $\boldsymbol{C}$, Case 30 (MALT lymphoma); Lane D, Case 37 (diffuse large B-cell lymphoma); Lane E, Case 39 (diffuse large B-cell lymphoma).

MALT lymphoma demonstrated a trisomy. Reactive lymphoid hyperplasia had no apparent chromosomal abnormalities as tested.

RT-PCR was performed in 37 cases of primary ocular malignant lymphomas (23 cases of MALT lymphoma, 2 cases of diffuse large B-cell lymphoma with MALT lymphoma, and 12 cases of diffuse large B-cell lymphoma without MALT lymphoma) and 6 cases of reactive lymphoid hyperplasia. All cases examined show clear actin amplification as internal control. The $\mathrm{t}(11 ; 18)(\mathrm{q} 21$; q21) translocation was detected by RT-PCR in 4 of 37 cases of malignant lymphomas tested: $2 / 23$ cases of MALT lymphoma (9\%) and 2/12 cases of diffuse large B-cell lymphoma without MALT lymphoma (17\%). RT-PCR also detected the $t(11 ; 18)(\mathrm{q} 21 ; \mathrm{q} 21)$ translocation in one of six cases of reactive lymphoid hyperplasia (17\%). The $t(11 ; 18)(q 21 ; q 21)$ translocation was detected only with the second PCR-A, and the amplified PCR products were all the same size, $147 \mathrm{bp}$ (Fig. 5). The results from the FISH and RT-PCR analyses are summarized in Table 3. FISH and/or RT-PCR disclosed the $\mathrm{t}(11 ; 18)(\mathrm{q} 21$; q21) translocation in one of eight cases of reactive lymphoid hyperplasia (13\%), 3 of 23 cases of MALT lymphoma (13\%), and 2 of 14 cases of diffuse large B-cell lymphoma with or without MALT lymphoma (14\%).

\section{DISCUSSION}

Ott et al. (11) first described the $\mathrm{t}(11 ; 18)(\mathrm{q} 21 ; \mathrm{q} 21)$ translocation as a frequent and specific chromosomal aberration in MALT lymphomas using a conventional cytogenetic analysis. However, conventional cytogenetic analysis requires fresh cell suspensions. In contrast, FISH and RT-PCR are use- ful tools to identify cytogenetic abnormalities in the interphase nuclei of formalin-fixed, paraffinembedded tissues. The two-color FISH assay using API2- and MALT1-specific probes for the detection of $\mathrm{t}(11 ; 18)(\mathrm{q} 21 ; \mathrm{q} 21)$ translocation was previously applied to MALT lymphomas of the stomach, lung, ocular adnexa, and other sites $(12,13)$. We also performed FISH analysis, but only for a limited number of cases because FISH requires cells isolated from relatively large paraffin sections.

RT-PCR for the detection of the $t(11 ; 18)(q 21 ; q 21)$ translocation has been described elsewhere (10, $14-16,24)$, and the results of the analyses on the $t(11 ; 18)$ translocation in MALT lymphomas of the stomach, lung, and ocular adnexa found in the literature $(10-16,24)$ are summarized in Table 4 . The incidence of $\mathrm{t}(11 ; 18)$ translocation has been reported to be $10-72 \%$ in MALT lymphomas of the stomach and $56-100 \%$ in pulmonary cases. However the $t(11 ; 18)$ translocation was not detected in any of the cases of ocular adnexal MALT lymphoma, although the number of cases was rather small. In the present study, 23 cases of MALT lymphoma in the ocular adnexa were analyzed by FISH and/or RT-PCR, disclosing 3 cases (13\%) positive for the $t(11 ; 18)$ translocation. This frequency is comparable to that of $t(11 ; 18)$-positive gastric MALT lymphoma in Japan, which is much lower than that in European patients. In case 17, the $t(11 ; 18)$ translocation was detected by FISH, but not by RT-PCR. This is likely due to the difference in the sampling methods or selection of PCR primers. Then, we tried to perform RT-PCR analysis with other PCR primer sets (10) to know the possibilities of false negative of RT-PCR. By this additional experiment, $t(11 ; 18)$ was not detected using frozen section by RT-PCR with other primer sets. The $\mathrm{t}(11$; 18) translocation has been much more frequently observed in MALT lymphomas of the lung. MALT lymphoma is a distinct lymphoma subtype, but the pathogenesis or cytogenetic characteristics of MALT lymphomas may differ depending on the anatomical location and also possibly on the patient's environmental or racial background.

The $\mathrm{t}(11 ; 18)$ translocation has not been detected in diffuse large B-cell lymphomas of the stomach $(11,16)$ a fact that has thrown doubt on the derivation of gastric diffuse large B-cell lymphomas from MALT lymphomas. The present study revealed the $t(11 ; 18)$ translocation in 2 of 12 cases of primary diffuse large B-cell lymphoma (17\%) of the ocular adnexa, none of which had a residual MALT lymphoma component. This evidence may suggest the possibility that some diffuse large B-cell lymphomas of the ocular adnexa are derived from MALT lymphomas. However, two cases of diffuse large B-cell lymphoma with MALT lymphomas were negative for the $t(11 ; 18)$ translocation. Furthermore, 
TABLE 3. Results of FISH and RT-PCR

\begin{tabular}{|c|c|c|c|c|c|c|c|c|c|c|}
\hline $\begin{array}{c}\text { Case } \\
\text { Number }\end{array}$ & Sex & $\begin{array}{l}\text { Age } \\
\text { (yrs) }\end{array}$ & Diagnosis & Site & $\begin{array}{c}\text { Follow-Up } \\
\text { Time } \\
\text { (months) }\end{array}$ & $\begin{array}{l}\text { Status at Last } \\
\text { Follow-Up }\end{array}$ & $\begin{array}{c}\text { Molecular Analysis } \\
\text { by Using PCR }\end{array}$ & $\begin{array}{c}\text { Molecular Analysis } \\
\text { by Southern } \\
\text { Blotting }\end{array}$ & FISH & RT-PCR \\
\hline 1 & M & 35 & RLH & Orbit & 103 & Died of NHL & Not clonal & n.d. & n.d. & - \\
\hline 2 & M & 62 & RLH & LG & 65 & Alive & Not clonal & Not clonal & n.d. & A \\
\hline 3 & $\mathrm{~F}$ & 70 & RLH & LG & 66 & Alive & Not clonal & Not clonal & n.d. & - \\
\hline 4 & M & 50 & RLH & Orbit & 44 & Alive & Not clonal & Not clonal & - & - \\
\hline (4) & & & & & & (Second biopsy) & Not clonal & Not clonal & - & n.d. \\
\hline 5 & $\mathrm{M}$ & 52 & $\mathrm{RLH}$ & LG & - & Lost to follow-up & Not clonal & Not clonal & - & n.d. \\
\hline 6 & M & 43 & RLH & LG & 23 & Alive & Not clonal & Not clonal & n.d. & - \\
\hline 7 & $\mathrm{~F}$ & 44 & RLH & LG & 43 & Alive & Not clonal & Not clonal & - & - \\
\hline 8 & $\mathrm{~F}$ & 69 & RLH & LG & 54 & Alive & Not clonal & Not clonal & n.d. & - \\
\hline 9 & $\mathrm{~F}$ & 63 & MALT & Orbit & 120 & Alive & n.d. & Clonal & n.d. & - \\
\hline 10 & $\mathrm{~F}$ & 39 & MALT & LG & 16 & Alive & Clonal & Clonal & - & - \\
\hline 11 & M & 76 & MALT & LG & 39 & Alive & Not clonal & Not clonal & n.d. & - \\
\hline 12 & M & 61 & MALT & Orbit & 60 & Alive & Not clonal & Not clonal & n.d. & - \\
\hline 13 & M & 56 & MALT & Orbit & 100 & Alive & n.d. & Not clonal & n.d. & - \\
\hline 14 & $\mathrm{~F}$ & 55 & MALT & LS & 98 & Alive & Clonal & Not clonal & n.d. & - \\
\hline 15 & $\mathrm{~F}$ & 64 & MALT & Conj. & 87 & Alive & Clonal & Not clonal & n.d. & - \\
\hline 16 & M & 67 & MALT & Conj. & 64 & Alive & Not clonal & Not clonal & n.d. & - \\
\hline 17 & M & 67 & MALT & Orbit & 87 & Alive & Clonal & Clonal & $\mathrm{t}(11 ; 18)$ & - \\
\hline 18 & $\mathrm{~F}$ & 64 & MALT & Conj. & 84 & Alive & Not clonal & Not clonal & n.d. & - \\
\hline 19 & $\mathrm{~F}$ & 67 & MALT & Orbit & 18 & Alive & Not clonal & Clonal & n.d. & - \\
\hline 20 & M & 71 & MALT & Orbit & 12 & Alive & Not clonal & n.d. & n.d. & - \\
\hline 21 & M & 56 & MALT & Orbit & 7 & Alive & Clonal & Not clonal & n.d. & - \\
\hline 22 & $\mathrm{~F}$ & 27 & MALT & Conj. & 71 & Alive & Clonal & n.d. & n.d. & - \\
\hline 23 & $\mathrm{~F}$ & 57 & MALT & LG & 59 & Alive & n.d. & n.d. & n.d. & - \\
\hline 24 & $\mathrm{~F}$ & 57 & MALT & Conj. & 26 & Alive & Clonal & n.d. & n.d. & - \\
\hline 25 & M & 61 & MALT & Orbit & 20 & Alive & Clonal & Not clonal & n.d. & - \\
\hline 26 & M & 53 & MALT & Conj. & 27 & Alive & Clonal & Clonal & - & - \\
\hline 27 & $\mathrm{~F}$ & 60 & MALT & Conj. & 13 & Alive & n.d. & n.d. & n.d. & - \\
\hline 28 & M & 79 & MALT & Orbit & - & Lost to follow-up & n.d. & n.d. & trisomy 3 & - \\
\hline 29 & $\mathrm{~F}$ & 29 & MALT & Conj. & 6 & Alive & n.d. & n.d. & n.d. & - \\
\hline 30 & $\mathrm{~F}$ & 47 & MALT & LG & 12 & Alive & n.d. & n.d. & n.d. & A \\
\hline 31 & $\mathrm{~F}$ & 49 & MALT & Orbit & 37 & Alive & n.d. & n.d. & n.d. & - \\
\hline 32 & $\mathrm{~F}$ & 86 & DLBCL+MALT & LG & 11 & Alive & Not clonal & n.d. & trisomy 18 & - \\
\hline 33 & $\mathrm{~F}$ & 65 & DLBCL+MALT & Orbit & 1 & DWD & n.d. & n.d. & n.d. & - \\
\hline 34 & M & 80 & DLBCL & Orbit & - & Lost to follow-up & n.d. & n.d. & n.d. & - \\
\hline 35 & M & 66 & DLBCL & LG & 4 & DWD & n.d. & n.d. & n.d. & - \\
\hline 36 & $\mathrm{~F}$ & 67 & DLBCL & LG & 111 & Alive & Clonal & n.d. & trisomy $7+$ tetrasomy 18 & - \\
\hline 37 & $\mathrm{~F}$ & 64 & DLBCL & Orbit & 35 & DWD & Clonal & n.d. & n.d. & A \\
\hline 38 & M & 74 & DLBCL & LG & 20 & Died NED & n.d. & n.d. & trisomy 3 & - \\
\hline 39 & M & 75 & DLBCL & Conj. & 30 & Alive & Clonal & Clonal & $\mathrm{t}(11 ; 18)+$ trisomy 18 & A \\
\hline 40 & M & 56 & DLBCL & Conj. & 25 & Alive & Not clonal & n.d. & n.d. & - \\
\hline 41 & $\mathrm{~F}$ & 65 & DLBCL & Orbit & 39 & Alive & n.d. & n.d. & n.d. & - \\
\hline 42 & $\mathrm{~F}$ & 73 & DLBCL & Orbit & 19 & Alive & n.d. & n.d. & n.d. & - \\
\hline 43 & $\mathrm{~F}$ & 74 & DLBCL & Conj. & - & Lost to follow-up & n.d. & n.d. & n.d. & - \\
\hline 44 & M & 69 & DLBCL & Orbit & 2 & Alive & n.d. & n.d. & n.d. & - \\
\hline 45 & $\mathrm{~F}$ & 40 & DLBCL & Orbit & 18 & DWD & n.d. & n.d. & n.d. & - \\
\hline
\end{tabular}

$\mathrm{RLH}=$ reactive lymphoid hyperplasia; MALT = mucosa-associated lymphoid tissue lymphoma; DLBCL = diffuse large B-cell lymphoma; LG = lacrimal gland; LS = lacrimal sac; Conj. = conjunctiva; n.d. = not done; - = negative; A = positive for RT-PCR product A (PCR-A); DWD = died with the disease; $\mathrm{NED}=$ no evidence of the disease.

TABLE 4. Incidence of the $t(11 ; 18)$ Chromosomal Translocation in MALT Lymphomas

\begin{tabular}{|c|c|c|c|c|c|}
\hline \multirow{2}{*}{ Authors } & \multicolumn{3}{|c|}{ Number of Positive Cases/Number of Cases Examined (\%) } & \multirow{2}{*}{ Method } & \multirow{2}{*}{ Reference } \\
\hline & Stomach & Lung & Ocular adnexa & & \\
\hline Ott et al. & $4 / 10(40)$ & $2 / 2(100)$ & $0 / 1(0)$ & Karyotype & 11 \\
\hline Rosenwald et al. & $7 / 21(33)$ & $1 / 1(100)$ & $0 / 3(0)$ & FISH & 12 \\
\hline Dierlamm et al. & $6 / 24(25)$ & - & $0 / 5(0)$ & FISH & 13 \\
\hline Kalla et al. & $13 / 18(72)$ & $2 / 2(100)$ & - & FISH/RT-PCR & 14 \\
\hline Motegi et al. & $1 / 11(10)$ & $5 / 9(56)$ & - & RT-PCR & 15 \\
\hline Beans et al. & $11 / 23(48)$ & - & - & RT-PCR & 16 \\
\hline Inagaki et al. & 1/8 (13) & $3 / 4(75)$ & - & RT-PCR & 24 \\
\hline Liu et al. & $19 / 56(34)$ & $4 / 7$ (57) & $0 / 1(0)$ & RT-PCR & 10 \\
\hline The present study & - & - & $3 / 23$ (13) & FISH/RT-PCR & - \\
\hline
\end{tabular}

only a small portion of MALT lymphomas of the ocular adnexa showed the $t(11 ; 18)$ translocation. Thus, further studies are required before drawing a definite conclusion. In addition, polysomies were observed more frequently in diffuse large B-cell lymphomas than in MALT lymphomas. However 
the limited number of cases examined did not allow for a statistical analysis.

In reactive lymphoid hyperplasia of the ocular adnexa, only one case demonstrated the $t(11 ; 18)$ translocation by RT-PCR, but the rearrangement of immunoglobulin heavy chain genes was not detected by PCR using primers directed to the framework 2 region and to the joining region (previous report [17]). RT-PCR is so sensitive that it could detect only a small number of $t(11 ; 18)$-positive cells among lymphoid cells in reactive lymphoid hyperplasia. This suggests that the $t(11 ; 18)$ translocation is a manifestation of the spectrum of diseases and so that patients with reactive lymphoid hyperplasia need to be followed as MALT lymphomas may be derived from reactive lymphoid hyperplasia.

In conclusion, the $\mathrm{t}(11 ; 18)(\mathrm{q} 21 ; \mathrm{q} 21)$ translocation was detected in $13 \%$ of reactive lymphoid hyperplasia cases, $13 \%$ of MALT lymphoma cases, and $14 \%$ of diffuse large B-cell lymphoma cases with/without MALT lymphoma components by FISH and/or multiplex RT-PCR using formalin-fixed, paraffinembedded materials. At least in the ocular adnexa, some MALT lymphomas and diffuse large B-cell lymphomas are positive for $\mathrm{t}(11 ; 18)(\mathrm{q} 21 ; \mathrm{q} 21)$ translocation. These results suggest that some diffuse large B-cell lymphomas may arise from MALT lymphomas.

Acknowledgments: We thank Dr. T. Mannami, Dr. S. Nakamura, Dr. Y. Sato, and Dr. T.S. Sakugawa for clinical discussions and Dr. H. Otsuki, Dr. M. Okabe, and Dr. S. Nakamura for providing the samples. Dr. K. Nomura assisted greatly in two-color FISH studies. Excellent technical assistance was given by $M$. Okabe and S. Onoda in immunohistochemistry and Southern blotting analysis.

\section{REFERENCES}

1. Isaacson PG, Dennis H. Malignant lymphoma of mucosaassociated lymphoid tissue. Cancer 1983;52:1410-6.

2. Harris NL, Jaffe ES, Stein H, Banks PM, Chan JK, Cleary ML, et al. A revised European-American classification of lymphoid neoplasms: a proposal from the International Lymphoma Study Group. Blood 1994;84:1361-92.

3. Isaacson PG, Berger F, Müller-Hermelink HK, Nathwani BN, Piris MA, Swerdlow SH, et al. Extranodal marginal zone B-cell lymphoma of mucosa-associated lymphoid tissue (MALT lymphoma). In: Jaffe ES, Harris NL, Stein H, Vardiman JW, editors. Tumor of haematopoietic and lymphoid tissues. World Health Organization classification of tumours. Lyon, France: IARC Press; 2001. p. 157-60.

4. Wotherspoon AC, Pan L, Diss TC, Isaacson PG. Cytogenetic study of B-cell lymphoma of mucosa-associated lymphoid tissue. Cancer Genet Cytogenet 1992;58:35-8.

5. Wotherspoon AC, Finn TM, Isaacson PG. Trisomy 3 in lowgrade B-cell lymphomas of mucosa-associated lymphoid tissue. Blood 1995;85:2000-4.
6. Dierlamm J, Michaux L, Wlodarska I, Pittaluga S, Zeller W, Stul M, et al. Trisomy 3 in marginal zone B-cell lymphoma: a study based on cytogenetic analysis and fluorescence in situ hybridization. Br J Haematol 1996;93:242-9.

7. Brynes RK, Almaguer PD, Leathery KE, McCourty A, Arber DA, Medeiros LJ, et al. Numerical cytogenetic abnormalities of chromosomes 3, 7, 12 and 18 in marginal zone B-cell lymphomas. Mod Pathol 1996;9:995-1000.

8. Blanco R, Lyda M, Davis B, Kraus M, Fenoglio-Preiser C. Trisomy 3 in gastric lymphomas of extranodal marginal zone B-cell (mucosa-associated lymphoid tissue) origin demonstrated by FISH in intact paraffin tissue sections. Hum Pathol 1999;30:706-11.

9. Du MQ, Peng H, Liu H, Hamoudi RA, Diss TC, Willis TG, et al. BCL10 gene mutation in lymphoma. Blood 2000;95:3885-90.

10. Liu H, Ye H, Dogan A, Ranaldi R, Hamoudi RA, Bearzi I, et al. $\mathrm{t}(11 ; 18)(\mathrm{q} 21 ; \mathrm{q} 21)$ is associated with advanced mucosaassociated lymphoid tissue lymphoma that expresses nuclear BCL10. Blood 2001;98:1182-7.

11. Ott G, Katzenberger T, Greiner A, Kalla J, Rosenwald A, Heinrich $U$, et al. The $t(11 ; 18)(q 21 ; q 21)$ chromosome translocation is a frequent and specific aberration in low-grade but not high-grade malignant non-Hodgkin's lymphomas of mucosa-associated lymphoid tissue (MALT-) type. Cancer Res 1997;57:3944-8.

12. Rosenwald A, Ott G, Stilgenbauer S, Kalla J, Bredt M, Katzenberger T, et al. Exclusive detection of $\mathrm{t}(11 ; 18)(\mathrm{q} 21 ; \mathrm{q} 21)$ in extranodal marginal zone B cell lymphomas (MZBL) of MALT type in contrast to other MZBL and extranodal large B cell lymphomas. Am J Pathol 1999;155:1817-21.

13. Dierlamm J, Baens M, Stefanova-Ouzounova M, Hinz K, Wlodarska I, Maes B, et al. Detection of t(11;18)(q21;q21) by interphase fluorescence in situ hybridization using API2 and MLT specific probes. Blood 2000;96:2215-8.

14. Kalla J, Stilgenbauer S, Schaffner C, Wolf S, Ott G, Greiner A, et al. Heterogeneity of the API2-MALT1 gene rearrangement in MALT-type lymphoma. Leukemia 2000;14:1967-74.

15. Motegi M, Yonezumi M, Suzuki H, Suzuki R, Hosokawa Y, Hosaka S, et al. API2-MALT1 chimeric transcripts involved in mucosa-associated lymphoid tissue type lymphoma predict heterogenous products. Am J Pathol 2000;156:807-12.

16. Baens M, Maes B, Steyls A, Geboes K, Wolf-Peeters CD. The product of the $\mathrm{t}(11 ; 18)$, an API2-MLT fusion, marks nearly half of gastric MALT type lymphomas without large cell proliferation. Am J Pathol 2000;156:1433-9.

17. Mannami T, Yoshino T, Oshima K, Takase S, Kondo E, Ohara $\mathrm{N}$, et al. Clinical, histopathological, and immunogenetic analysis of ocular adnexal lymphoproliferative disorders: characterization of MALT lymphoma and reactive lymphoid hyperplasia. Mod Pathol 2001;14:641-9.

18. Isaacson PG, Norton AJ. Extranodal lymphomas. Edinburgh, UK: Churchill Livingstone; 1994.

19. Akagi T, Tamura A, Motegi M, Suzuki R, Hosokawa Y, Nakamura S, et al. Molecular cytogenetic delineation of breakpoint at 18q21.1 in low-grade B-cell lymphoma of mucosaassociated lymphoid tissue. Genes Chromosomes Cancer 1999;24:315-21.

20. Akagi T, Motegi M, Tamura A, Suzuki R, Hosokawa Y, Suzuki H, et al. A novel gene, MALT1 at 18q21, is involved in $\mathrm{t}(11 ; 18)(\mathrm{q} 21$; q21) found in low-grade B-cell lymphoma of mucosaassociated lymphoid tissue. Oncogene 1999;18:5785-94.

21. Lengauer C, Green ED, Cremer T. Fluorescence in situ hybridization of YAC clones after Alu-PCR amplification. Genomics 1992;13:826-8.

22. Hyytinen E, Visakorpi T, Kallooniemi A, Kallioniemi OP, Isola JJ. Improved technique for analysis of formalin-fixed, paraffin-embedded tumors by fluorescence in situ hybridization. Cytometry 1994;16:93-9. 
23. Lichter P, Bentz M, Joos S. Detection of chromosomal aberrations by means of molecular cytogenesis: painting of chromosomes and chromosomal subregion and comparative genomic hybridization. Methods Enzymol 1995;254:334-59.
24. Inagaki $H$, Okabe $M$, Seto $M$, Nakamura S, Ueda R, Eimoto T. API2-MALT1 fusion transcripts involved in mucosaassociated lymphoid tissue lymphoma. Am J Pathol 2001; 158:699-706.

\section{Book Review}

\section{Smith CUM: Elements of Molecular Neurobiol- ogy, 3rd Edition, 630 pp, Hoboken, NJ, John Wiley \& Sons, 2002 (\$165.00).}

A concise and current textbook of the basic concepts in molecular neurobiology, this book provides the foundation for an understanding of the molecular basis of neurobiology. It is a wealth of basic information and a serious starting point for undergraduate students, neuroscience students, molecular biologists, pharmacologists, and researchers who want a concise introduction to the field. The success of the book is illustrated by the fact that this is the third edition since 1989. The author should be congratulated not only for the valuable integration of the important aspects of molecular biology in neuroscience but also for relatively early recognition of the need for a modern textbook on this rapidly developing field.

The main feature of this book is the wellbalanced amount of information provided in each chapter. Well-structured and up-to-date chapters, glossary, five appendices (Molecules and Consciousness, Units, Data, Genes, Physical Models of Ion Conduction), an index of neurological diseases, and a very helpful high-yield bibliography (excellent selection of the most important reviews) make this book really complete and one of the best sources for learning. The bibliography also provides Web sites relevant for each chapter. It is a new and very useful feature and provides a good introduction to further study. Among many other innovations, it represents the inventive and modern author's approach. The book is well-illustrated, and it successfully presents complex ideas visually. Some continuing controversial issues in neuroscience are represented in a fair and unbiased way. Basic concepts as well as recent developments in clinical and basic neuroscience likely to assist in the understanding of the relevant neurological disorders are included and well-explained. All these features are especially important for students.

I recommend this book because it brings together a wide range of current concepts in a compact and well-edited volume. This unique, easy to read book serves as an excellent source for studying as well as a ready and accessible reference that will be a great help to its readers. It already has a well-earned place on the neuroscience students' reference shelf.

\author{
Vicko Gluncic \\ Yale University School of Medicine \\ New Haven, Connecticut
}

